\title{
Study on the Distribution Model of Supermarket Chain Based on AHP
}

\author{
Caixia Chen and Chun Shi \\ Department of E-commerce, School of Information Science and Technology, \\ Hainnan Normal University, Haikou 571158, P.R. China. \\ *Corresponding Author
}

\begin{abstract}
In the past few years, With the constant expansion of supermarket chains, logistic distribution has been a Bottleneck of the development of supermarket chains. It is an important reason that distribution model is not well chose. This article based on the analysis of the limitation of traditional selective means and point out the factors for choosing distribution model.By using AHP, author build a decision model of choosing distribution model. This model will make it more reasonable when choosing distribution model.
\end{abstract}

Keywords: supermarket chain; distribution model; AHP

\section{INTRODUCTION}

As a kind of modern business model and organizational form, chain operation has become a major trend in the development of retail industry in China and even in the world. As a typical representative of chain operation, chain supermarket has broad prospects for development.

At the same time, with the diversification of expanding chain supermarket scale and format, the supermarket merchandise for many varieties, multi batch, small batch delivery requirements will be more and more intense, the high cost of logistics, the logistics distribution has become the key point of supermarket competition, how to choose the mode of distribution, has very important significance for enterprise.

\section{Overview of LOGISTICS Distribution Mode}

There are four types of logistics distribution modes

\section{A. Direct Supplier Mode}

Supplier direct distribution is determined by the supplier chain headquarters, each branch will be goods information feedback to the headquarters, unified by the headquarters to supplier branch orders.

- The advantage of direct distribution is: reducing the intermediate links, reducing the logistics cost, ease of reverse logistics.

- The disadvantage of direct distribution is: to establish a perfect supply chain inventory management information system, virtually increased both the cost of the two sides, inventory costs also increased.

\section{B. Self Distribution Mode}

Self distribution refers to the chain enterprises to establish their own distribution center, the headquarters of the chain supermarket distribution center for business management, the completion of the distribution of all the business operations.

- Self distribution has the advantage of: enterprise management autonomy and the plan is strong, easy to keep the chain enterprise business secret.

- The disadvantages of self distribution is: capital investment, the number of stores enough to have enough, busy idle phenomenon is obvious, easy to manage.

\section{Third Party Logistics}

Third party logistics distribution refers to the chain enterprises to complete the distribution business entrusted to the third party logistics enterprises to operate a distribution mode of operation.

- The advantage of the third party logistics distribution is: reduce the number of invalid inventory, shorten the time of inventory, improve the cash flow of enterprises, improve customer satisfaction.

- The shortcomings of the third party logistics distribution: the enterprise is in a passive position, can not guarantee the accurate and timely delivery and service, need to choose a number of third party logistics enterprises, there is a certain degree of risk and uncertainty.

\section{Common Distribution Model}

Joint distribution chain enterprises refers to a certain amount of investment, commissioned by the unified specific suppliers to establish a distribution center in a region, collecting the various suppliers of similar products, and centralized distribution to the chain stores within the region.

- The advantage of joint distribution is that: to reduce the cost of logistics, improve the satisfaction of consumers, enhance the image of the chain enterprises.

- The disadvantage of the joint distribution is that: the enterprise needs a strong ability to deal with information, is not suitable for small and medium-sized chain enterprises. 


\section{CHAIN SUPERMARKET LOGISTICS AND DISTRIBUTION}

\section{A. Logistics Distribution Characteristics of Supermarket Chains:}

- Unified procurement, transportation, economies of scale. The supermarket chain stores. The headquarters of unified procurement, and in accordance with the unified marketing strategy and a branch of commodity varieties, specifications and other requirements, unified transport. The two unified the supermarket chain realization of large quantities of goods and transport into integration, economies of scale.

- Order quantity is small, the frequency is high. In order to guarantee the minimum inventory of the chain supermarket, the quantity of the supermarket chains is small, and the distribution of the high frequency to meet the needs of the stores.

- There is a variety of goods, transport and storage requirements of diversification. The supermarket chain in order to fully meet the needs of the consumers, sales of all stores within the wide range of goods, involving food, daily consumer goods and has the characteristics of supermarket fresh food. So the distribution and storage requirements of the present diversification trend.

- Reverse logistics is common. High frequency characteristics and customer service sales service commitment of the supermarket chain makes the supermarket chain commodity renewal, the damage rate is relatively high, resulting in the return frequency and quantity is relatively large.

\section{B. Analysis on the Influencing Factors of Distribution Mode of Chain Supermarket}

Distribution is the core of the supermarket chain, need to have a set of scientific, complete, the index system can reflect the distribution mode of chain enterprises from all angles. The distribution cost and delivery service is the two most important factors of choosing distribution mode of chain enterprises, the choice of goods characteristics of the distribution pattern also plays a certain role. When general chain enterprises will also take into account the development of the regional economy in considering the distribution mode, logistics network development level and the support of information technology. In addition, some influence the choice of government policy and market environment for the supermarket chain distribution mode. Therefore, the factors can be summarized as the following distribution mode selection several aspects: cost factors, service factors, environmental factors, product characteristics and so on.

\section{1) Cost factor}

Any enterprise managers want the minimum of the cost of their own business activities, the maximum profit, so the distribution cost is the core elements of the chain supermarket must be considered in the choice of delivery mode. The general logistics cost includes the cost of operation, the cost of investment, investment risk, portfolio benefits and resource configuration of these four aspects.

\section{2) Servicing factor}

The basic service of chain supermarket logistics refers to the supermarket in the basic logistics activities, provide customer service commitment. With the increased competition, maximize the more conscious pursuit of the lowest cost and can not bring profits to the supermarket chain. And distribution service level is directly related to the competitiveness of the supermarket chain the basic measure of logistics service quality. The index mainly includes three aspects of availability, performance and reliability.

3) Environmental factor

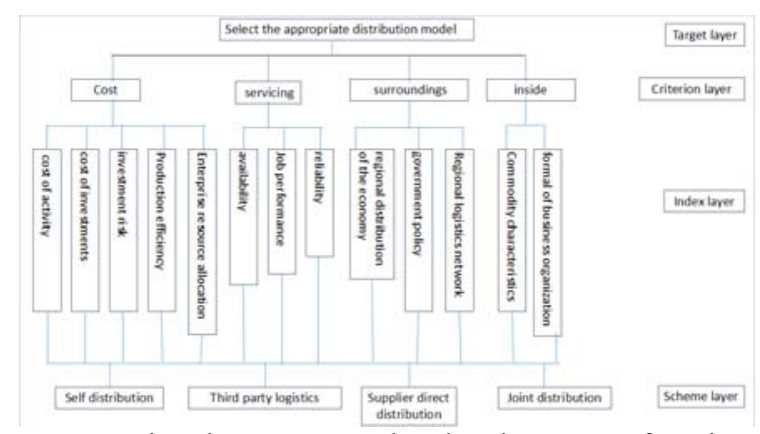

Regional Economy: the development of regional economy has an important role in the future development of the supermarket chain, the more optimistic about the prospects of regional economic development, the size of the chain supermarket is also expected to expand.

- Government policy: the construction of logistics system is a long-term and arduous task, if the government is given a distribution mode in a certain period of time (such as self built distribution center) some policy support, so for the basic conditions of the supermarket chain, will tend to the distribution modes selection of government policy support.

- Regional logistics network development: the development of the regional logistics market, logistics market is standardized, the corresponding laws and regulations of the logistics service is perfect, it will affect the decision makers of chain supermarket logistics distribution mode selection.

\section{4) Internal factors}

The internal factors are divided into two categories: commodity characteristics and enterprise form.

- Product features: some goods distribution has special requirements such as fresh, frozen goods, have special requirements on the delivery tool, usually by the supplier. The direct distribution of certain goods because of strict requirements on the transport time (such as the short shelf life of goods), need to compress the intermediate links, generally do not consider the third party logistics however, often through supplier direct distribution mode.

- Enterprise form: different chain supermarket form of logistics and distribution of the demand is not the same, according to the size of the enterprise to set. 
IV. XX DistribUTION MODEL DESIGN OF SUPERMARKET

\section{A. Establish Hierarchy Model}

On the basis of the analysis of the distribution model, the factors which affect the distribution model are constructed as follows:

Fig 4-1 Hierarchical structure diagram

\section{B. Structure Judgment Matrix}

After the establishment of the hierarchical structure, relationship between the upper and lower level elements was determined. Using the judgment matrix to represent all weights. So the rules of $\mathrm{B}, \mathrm{n}$ by comparison of elements constitutes a Pairwise comparison judgment matrix:

$$
B=\left(\mathrm{c}_{i j}\right)_{n^{2}}
$$

Among them, $\mathrm{C}_{\mathrm{ij}}$ is the scale of the importance of element $C_{i}$ and $C_{j}$ relative to $B$, it has the following properties:

$$
\left\{\begin{array}{l}
c_{i j}=1 \quad(\mathrm{i}=\mathrm{j}) \\
c_{i j}=\frac{1}{C_{n}} \quad(\mathrm{i}, \mathrm{j}=1,2, \ldots \ldots . \mathrm{n})
\end{array}\right.
$$

On how to determine the value of $\mathrm{C}_{\mathrm{ij}}$, Saaty, such as the proposed digital 1 9 and its reciprocal as the scale, and provides its meaning ${ }^{[4]}$, Table I. :

\begin{tabular}{|c|c|}
\hline Scale & Meaning \\
\hline 1 & Indicates that the two factors are of the same importance. \\
\hline 3 & $\begin{array}{c}\text { Compared with the latter, the former is a little more } \\
\text { important than the latter two factors. }\end{array}$ \\
\hline 5 & $\begin{array}{l}\text { Compared with the latter, the former is more important } \\
\text { than the latter, which indicates the two factors. }\end{array}$ \\
\hline 7 & $\begin{array}{l}\text { Compared with the latter, the former is more important } \\
\text { than the latter, which indicates the two factors. }\end{array}$ \\
\hline 9 & $\begin{array}{l}\text { Compared to the two factors, the former is more } \\
\text { important than the latter. }\end{array}$ \\
\hline $2,4,6,8$ & The intermediate value of the adjacent judgment \\
\hline
\end{tabular}

TABLE I. SCALE AND MEANING TABLE

Through the investigation of the XX supermarket chain, and obtain some basic data on the choice of the logistics distribution mode, and the data synthesize, obtained are as follows: Table II judgment matrix judgment matrix criterion layer; table III, table IV and V judgment matrix index layer; table VI. judgment matrix scheme layer.
TABLE II. B JUDGMENT MATRIX ON A

\begin{tabular}{|c|c|c|c|c|}
\hline $\mathrm{A}$ & $\begin{array}{c}\text { Cost } \\
\mathrm{B}_{1}\end{array}$ & $\begin{array}{c}\text { Service } \\
\mathrm{B}_{2}\end{array}$ & $\begin{array}{c}\text { Surroundings } \mathrm{B}_{3} \\
\text { Inside } \\
\mathrm{B}_{4}\end{array}$ \\
\hline Cost $\mathrm{B}_{1}$ & 1 & 3 & 4 & 7 \\
\hline Service $\mathrm{B}_{2}$ & $1 / 3$ & 1 & 3 & 5 \\
\hline $\begin{array}{c}\text { Surroundings } \\
\mathrm{B}_{3}\end{array}$ & $1 / 4$ & $1 / 3$ & 1 & 2 \\
\hline Inside $\mathrm{B}_{4}$ & $1 / 7$ & $1 / 5$ & $1 / 2$ & 1 \\
\hline
\end{tabular}

TABLE III. C JUDGMENT MATRIX ON $\mathrm{B}_{1}$

\begin{tabular}{|c|c|c|c|c|}
\hline Cost $\mathrm{B}_{1}$ & $\mathrm{C}_{1}$ & $\mathrm{C}_{2}$ & $\mathrm{C}_{3}$ & $\mathrm{C}_{4}$ \\
\hline $\mathrm{C}_{1}$ & 1 & $1 / 7$ & $1 / 3$ & $1 / 5$ \\
\hline $\mathrm{C}_{2}$ & 7 & 1 & 5 & 2 \\
\hline $\mathrm{C}_{3}$ & 3 & $1 / 5$ & 1 & $1 / 2$ \\
\hline $\mathrm{C}_{4}$ & 5 & $1 / 2$ & 2 & 1 \\
\hline
\end{tabular}

TABLE IV. C JUDGMENT MATRIX ON B 2 AND B 3

\begin{tabular}{|c|c|c|c|c|c|c|c|}
\hline $\begin{array}{c}\text { service } \\
\mathrm{B}_{2}\end{array}$ & $\mathrm{C}_{1}$ & $\mathrm{C}_{2}$ & $\mathrm{C}_{3}$ & $\begin{array}{c}\text { environ } \\
\text { ment } \\
\mathrm{B}_{3}\end{array}$ & $\mathrm{C}_{1}$ & $\mathrm{C}_{2}$ & $\mathrm{C}_{3}$ \\
\hline $\mathrm{C}_{1}$ & 1 & 4 & 7 & $\mathrm{C}_{1}$ & 1 & $1 / 4$ & $1 / 2$ \\
\hline $\mathrm{C}_{2}$ & $1 / 4$ & 1 & 2 & $\mathrm{C}_{2}$ & 4 & 1 & 3 \\
\hline $\mathrm{C}_{3}$ & $1 / 7$ & $1 / 2$ & 1 & $\mathrm{C}_{3}$ & 2 & $1 / 3$ & 1 \\
\hline
\end{tabular}

TABLE V. C JUDGMENT MATRIX ON B 4

\begin{tabular}{|c|c|c|}
\hline Inside $\mathrm{B}_{4}$ & $\mathrm{C}_{1}$ & $\mathrm{C}_{2}$ \\
\hline $\mathrm{C}_{1}$ & 1 & $1 / 3$ \\
\hline $\mathrm{C}_{2}$ & 3 & 1 \\
\hline
\end{tabular}

TABLE VI. D JUDGMENT MATRIX ON $\mathrm{C}_{11}$

\begin{tabular}{|l|l|l|l|l|}
\hline $\mathrm{C}_{11}$ & $\mathrm{D}_{1}$ & $\mathrm{D}_{2}$ & $\mathrm{D}_{3}$ & $\mathrm{D}_{4}$ \\
\hline $\mathrm{D}_{1}$ & 1 & 2 & 7 & 2 \\
\hline $\mathrm{D}_{2}$ & $1 / 2$ & 1 & 5 & $1 / 2$ \\
\hline $\mathrm{D}_{3}$ & $1 / 7$ & $1 / 5$ & 1 & $1 / 6$ \\
\hline $\mathrm{D}_{4}$ & $1 / 2$ & 2 & 6 & 1 \\
\hline
\end{tabular}

C. Relative Weight Calculation and Consistency Check

For judgment matrix A, The computation satisfies $\mathrm{AW}=\lambda$ MAX W's characteristic root and characteristic vector.

The result is calculated in turn:

$W_{2}^{0} W_{3}^{0} W_{4}^{0}$ The results were: 27、0.12、0.062。 
- $\mathrm{B}_{1}, \mathrm{~B}_{2}, \mathrm{~B}_{3}, \mathrm{~B}_{4}$ relative to the weight of $\mathrm{A}: 0.54$ 、 $0.27 、 0.12 、 0.062$ 。

- The judgment matrix of the random consistency index CR: table VII. (indicator layer), table VIII (program layer).

- Combined weight consistency checking (D) $=(0.296,0.254,0.219,0.157)$, Total order consistency ratio $\mathrm{C} \cdot \mathrm{R} .=0.034<0.1$, So the decision result is credible.

TABLE VII. C $_{\text {IJ }}$ ON THE B JUDGMENT MATRIX CALCULATION RESULTS

\begin{tabular}{|c|c|c|c|c|}
\hline$W_{B k}(C i j)$ & $\mathrm{B}_{1}$ & $\mathrm{~B}_{2}$ & $\mathrm{~B}_{3}$ & $\mathrm{~B}_{4}$ \\
\hline & & & & \\
& 0.056 & 0.71 & 0.134 & 0.25 \\
$\mathrm{C}_{\mathrm{ij}}$ & 0.502 & 0.193 & 0.611 & 0.75 \\
& 0.285 & 0.097 & 0.255 & \\
\hline$\lambda_{\text {max }}$ & 4.074 & 3.003 & 3.023 & \\
\hline & $0.027<0$. & $0.003<0$. & $0.022<0$. & $\begin{array}{c}\text { two order } \\
\text { matrix is } \\
\text { always } \\
\text { consistent }\end{array}$ \\
\hline
\end{tabular}

TABLE VIII. D THE RESULT OF THE JUDGMENT MATRIX OF $\mathrm{C}_{\mathrm{IJ}}$

\begin{tabular}{|c|c|}
\hline$W_{C i j}(D i)$ & $\mathrm{C}_{11}$ \\
\hline $\mathrm{D}_{1}$ & 0.4 \\
$\mathrm{D}_{2}$ & 0.233 \\
$\mathrm{D}_{3}$ & 0.05 \\
$\mathrm{D}_{4}$ & 0.317 \\
& \\
\hline$C I_{C i j}$ & 0.035 \\
& \\
\hline$C R_{C i j}$ & $0.039<0.10$ \\
\hline
\end{tabular}

\section{Conclusion}

The calculation results show that the D1 logistics distribution mode is self distribution accounts for the largest proportion in the mode selection problem. So, XX can be drawn by the supermarket supplier direct distribution model for distribution, and the distribution mode of the supermarket is consistent.

\section{SUMMARY}

There are many methods of logistics distribution model, AHP method used in this paper is one of the more effective. This quantitative method, considering the multi factor decision-making model of logistics distribution mode of chain supermarket selection was given.

\section{ACKNOWLEDGMENT}

Thanks to the support by NSFC (No.61362016), Education Science Planning Office of Hainan Province (Hjjg2013-18).

\section{REFERENCES}

[1] Analysis report on the operation status of Chinese chain retail enterprises (2009-2010). China Chain Store, 2010.

[2] Qingyi wu, Logistics system engineering.beijing: China Business and Market, 2004: 194-196.

[3] Chunlin Li, Research on distribution mode of chain supermarket.Nanjing University Of Aeronautics And Astronautics, 2006.

[4] Yaojin Tan, Quantitative analysis method in Beijing. Beijing: China Remin University Press, 2003:124-150.

[5] Chun Wu, AHP evaluation method of logistics operation mode selection of chain retail enterprises in China. Technology \& Economy in Areas of Communications, 2005, 6.

[6] Zhaoxia Zhang, Chain supermarket logistics distribution mode optimization. Journal of Shanxi Institute of Economic Management, 2008, 16(4).

[7] Juan Gao, On the choice of logistics distribution mode of electronic commerce retail industry [J].Logistics Sci-Tech, 2010, 1.

[8] Rong $\mathrm{Li}$, Logistics distribution mode of chain enterprises in China[J].journal of huizhou university(Social Science Edition),2010,30(4) 